\title{
Is De Facto Partnership a Threat to Marriage? a Case Study from Macedonia
}

\author{
Irena Avirovic, Phd \\ Assistant Professor \\ avirovic@fzf.ukim.edu.mk \\ Makedonka Radulovic, PhD \\ Assistant Professor \\ radulovic@fzf.ukim.edu.mk \\ Institute of Family Studies, Faculty of Philosophy \\ University "SS. Cyril and Methodius", Skopje, Macedonia
}

"Changes in family relationships occur as macro-sociological changes in historical time, which take place over decades and centuries, but they also occur as micro-sociological changes during the lives of family members"1.

David Cheal, Families in Today's World, A Comparative Approach.

\begin{abstract}
The subject of this work is to examine whether the increased number of de facto partnerships could jeopardize the future of the marital institution in the Republic of Macedonia. The paper will provide existing statistical data on the number of marriages, divorces, and de facto partnerships in the country. Furthermore, it will analyze possible factors which have influenced the increased number of extra-marital communities in Macedonia. For the purposes of this paper we conducted a quantitative research with a sample of 120 respondents aged 18 to 22 years. The questionnaire was outlined to measure the perceptions of young people on marriage and cohabitation. In conclusion, the results from the respondents' answers were used as an inclusive consideration for future projections and possible major projects.
\end{abstract}

Keywords: cohabitation, marriage, divorce, Macedonia.

\section{Introduction}

With the development of contemporary societies, we are witnessing a continuous transformation of the family structure. Today, we have abandoned the classic description of family by George Murdock ${ }^{2}$, who defined family as a social group (composed by adults of both sexes and at least one child) characterized by reproduction, common residence and economic support. New types of families include: single-parent families, reconstituted families (i.e. "step" families where one or both

${ }^{1}$ Cheal D. (2008). Families in Today's World, A Comparative Approach. London; New York: Routledge, p. 107.

2 See more about Murdock's definition of family in Murdock, G. P. (1960). Social Structure. New York: Macmillan. 
partners have children from a previous marriage), homosexual marital and extra-marital communities, de facto partnerships and individual households. This pluralism of family models is a product of multiple processes: urbanization, industrialization, globalization, the influence of the Western world and the effect of Europeanization. ${ }^{1}$

In addition to the above-mentioned processes, Macedonia is facing a long period of political and economic transition which has additionally influenced the family structure and the society in general. The economic instability of the past two decades has caused increased labor migration in the European Union and overseas, resulting with an augmented number of families with at least one member of the household abroad. Moreover, with the introduction of the free market economy, the participation of women in the labor market led to further transformation of family roles. In fact, there is an ongoing debate on whether the increased economic emancipation of women in Macedonia is one of the main reasons for postponing marriage and birth.

Political, economic and social changes shape and transform family models as well. Macedonia has started to gradually abandon the patriarchal and extended family models, and substitute them primarily with nuclear families, but also with single-parent families and reconstituted family models, mainly due to the increased divorce rate. The nuclear family model, on the other hand, is undergoing through transformations by itself. In fact, in the past decade, traditional marriage appears to be challenged by the increased number of couples who choose to avoid the commitments of marital communities. Thus, following the example of Western societies, Macedonia has reduced the legal difference between cohabitation and marriage.

\section{Cohabitation}

According to the Family Law of the Republic of Macedonia, a de facto partnership or cohabitation is a community in which a man and a woman live at least one year without getting married. ${ }^{2}$ Macedonian extramarital communities enjoy the same rights of married couples as far as the right to mutual economic support and property rights are concerned, including legal protection against domestic violence. The Republic of Macedonia does not officially recognize any kind of same sex community, either marital or extra marital.

As stated by the Macedonian State Statistical Office, the number of marriages in 2014 decreased by $1,2 \%$ compared to 2013 , whilst the number of divorces increased with a share of $8,7 \%$ compared to the previous year. ${ }^{3}$ The contrast in numbers is significant when compared data from the first census of 1994 with more recent data. In almost one decade the number of marriages has decreased from 15.736 in 1994 to 13.982 in 2013, whilst the number of divorces has augmented from 710 in 1995 to 2.405 in 2013. ${ }^{4}$ There is already a significant change in numbers even if we analyze data from five years before. Namely, in 2009, the number of marriages and divorces had increased respectively by $1,6 \%$ and by $6,5 \%$ in comparison to the previous year. ${ }^{5}$ Whilst divorces continue to increase each year with a constant rate, the data regarding marriages is what caught our attention: from a continuous increasing rate, in just five years there is a significant decline ${ }^{6}$. This drop in numbers is caused by many factors; among the main causes postponing marriage for an older age and living in a de facto partnership are the dominant ones. According to the last official census of the Republic of Macedonia from

\footnotetext{
${ }^{1}$ Мицковиќ Д. (2008). Семејството во Европа XVI-XXI век, Скопје: Блесок, р. 209-220.

2Family Law, revised text, Part I, Art. 13, General Provisions, retrieved from: http://www.mtsp.gov.mk/wbstorage/files/zakon_semejstvo_osnoven.pdf (13/11/2015)

${ }^{3}$ Announcement on Marriages and Divorces by the State Statistical Office of the Republic of Macedonia, 11/06/2015, retrieved from: http://www.stat.gov.mk/PrikaziSoopstenie.aspx?rbrtxt=11 (17/03/2016)

${ }^{4}$ Regarding marriage and divorce in Macedonia see more in: Радуловиќ, М. (2014). Традицијата во европските и македонските семејства. Скопје: Култура.

${ }^{5}$ Announcement on Marriages and Divorces by the State Statistical Office of the Republic of Macedonia, 08/06/2010, retrieved from: http://www.stat.gov.mk/PrikaziSoopstenie.aspx?id=11\&rbr=95 (17/03/2016)

${ }^{6}$ Since 2008, through a series of legislative reforms, the Government of the Republic of Macedonia began to implement policies to stimulate and support families with three or more children, in order to increase fertility, including housing subventions for single people and young married couples under the age of 35 .
} 
2002, the official number of non-married couples living together with or without children was $6027^{1}$. However, new researches suggest a great increase of this number each year, with even higher estimates. Already in 2009 the number of children born in extramarital community represented $12,2 \%$ of the total number of born children in Macedonia. The same rate $(11,3 \%-12,2 \%)$ continued in the following five years as well. ${ }^{2}$

This trend was noted in the European Union much earlier. Main causes are considered to be: alterations of ethical and moral standards, general predominance of individualism, emancipation of women, sexual revolution and reduced influence of religion. As an example, in the European Union $40 \%$ children are born in a de facto partnership ${ }^{3}$ and the number of divorces has risen from 170.000 in 1960 to 1.040 .000 today. ${ }^{4}$ Compared to this figures, Macedonia's marital community might not be "at risk" at the present. However, if we consider that two decades ago Macedonia was at large a patriarchal society, where divorce and cohabitation were the exception and not the rule, then, this figures are worth major attention.

The expansion of de facto partnerships in Macedonia is a result of multiple emerging factors in our developing society. Among them, increased average age at first marriage, extended studies, postponed employment (due to studies or unemployment) and unresolved housing issue are the leading ones. ${ }^{5}$ In the period from 2009 to 2014 , the average age at first marriage ranged between 25 and 26 for women and $28-28,8$ for men. In the same period, the average age of women in the total number of births was 27,7-28,5 years old, and 25,9-26,8 years old for first born children. ${ }^{6}$ As far as higher education is concerned, the Republic of Macedonia has implemented the Bologna Process since 2010, thus the new system requires predominantly $3+2$ years of studies leading to a Master's degree. Longer studies postpone employment, hence financial independence and residency matters are postponed as well. In addition to the above-mentioned factors, nowadays younger generation enjoy free choice of lifestyle and feel less pressure from societal moral norms.

\section{Case study from Macedonia: Is de facto partnership a threat to marriage?}

In order to analyze the general opinion of youth in regard to marriage, divorce and cohabitation in Macedonia, during February and March 2016 we conducted a quantitative research with a sample of 120 respondents. Our focus group was students aged 18-22 years old. However, among the respondents seven answered to be between 23 and 26 years old and four are above 26 years old. Since the respondents were chosen randomly, we disregarded the possibility to conduct a gender balanced research at this stage of the investigation and the outcome was 22 male and 98 female respondents. The reason to put emphasis on the younger generation was to attempt a prediction on the possible future rates of marriage and de facto partnership in the country. Our questionnaire included 52 questions divided into five parts and was anonymously conducted. Due to limitation in space, for the purpose of this paper we used only part of the results, which are elaborated as follows.

As expected, the majority of the respondents live in nuclear families with parents living in a marital community. Almost $10 \%$ have divorced parents and there was no single case of de facto relationship. These results were not surprising, since cohabitation is a newly accepted trend in Macedonia and is not typical for the generation of our respondents' parents, which we estimate to be born in the late 1960s or early 1970s.

\footnotetext{
1 State Statistical Office of the Republic of Macedonia (2004). Census of Population, Households and Dwellings in the Republic of Macedonia, 2002, Final Data, Book XIII - Total Population according to Territorial Organization of the Republic of Macedonia. Skopje: State Statistical Office of the Republic of Macedonia, p.47.

2 Announcements on Population (2010-2015) by the State Statistical Office of the Republic of Macedonia, retrieved from: http://www.stat.gov.mk/PrikaziSoopstenie.aspx?id=8\&rbr=1723 (17/03/2016)

3 Share of Live Births outside Marriage according to Eurostat. See more data by country at: http:/lec.europa.eu/eurostatttgm/table.do?tab=table\&init=1\&language=en\&pcode=tps00018\&plugin=1 (16/03/2016)

${ }^{4}$ Мицковиќ, Д. ор.cit., p. 209-220.

${ }_{5}^{5}$ Борнарова, С. (2012). Социјална работа во семејството, Скопје: Универзитет Св. Кирил и Методиј, Филозофски факултет, р. 34-35.

${ }^{6}$ Announcements on Birth Rates (2010-2015) by the State Statistical Office of the Republic of Macedonia, retrieved from: http://www.stat.gov.mk/PrethodniSoopstenijaOblast.aspx?id=8\&rbrObl=2 (17/03/2016)
} 
Figure $1^{1}$

Status of respondents' parents in figures (Question \# 10: Your parents are...)

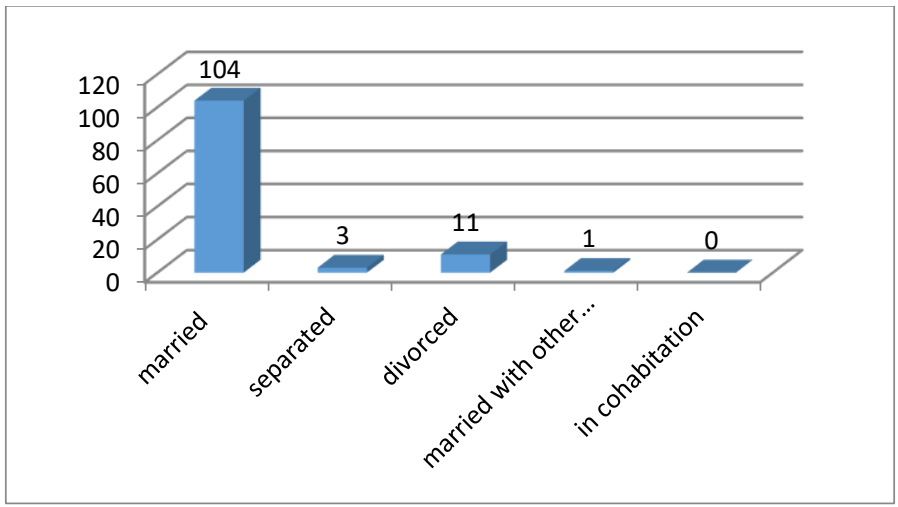

In the second section of the questionnaire we asked our respondents general opinions on marriage including reasons to get married, ideal age for marriage, advantages and disadvantages of being married. On the question whether married people are happier than single people, the majority responded positively (70 out of 120). This outcome correlates to the previous question and the fact that most respondents (104) come from families of married parents, which the majority has evaluated as harmonic (64) or well-functioning (49). The positive attitude towards marriage is confirmed with the results of answers from the statement "Everybody should get married": $55 \%$ respondents agreed and $45 \%$ disagreed with the statement. However, the negative answer from $45 \%$ of the respondents is already an indicator that for almost half of our students aged 18-22 not getting married is a possible option for themselves or other people. This liberal perception on marriage is more noticeably in the results of the following question: "Would you be in a relationship/marriage with a partner who has children from a previous relationship/marriage?" with $62,5 \%$ stating a positive answer. This result suggests that divorce and presumably having children outside marriage is acceptable and the possibility of dating a person with children from a previous relationship or marriage might be tolerable for their parents and/or family as well.

Figure 2. Opinion on happiness in marriage vs. singlehood (Question \# 18: Married people are happier than single people.)

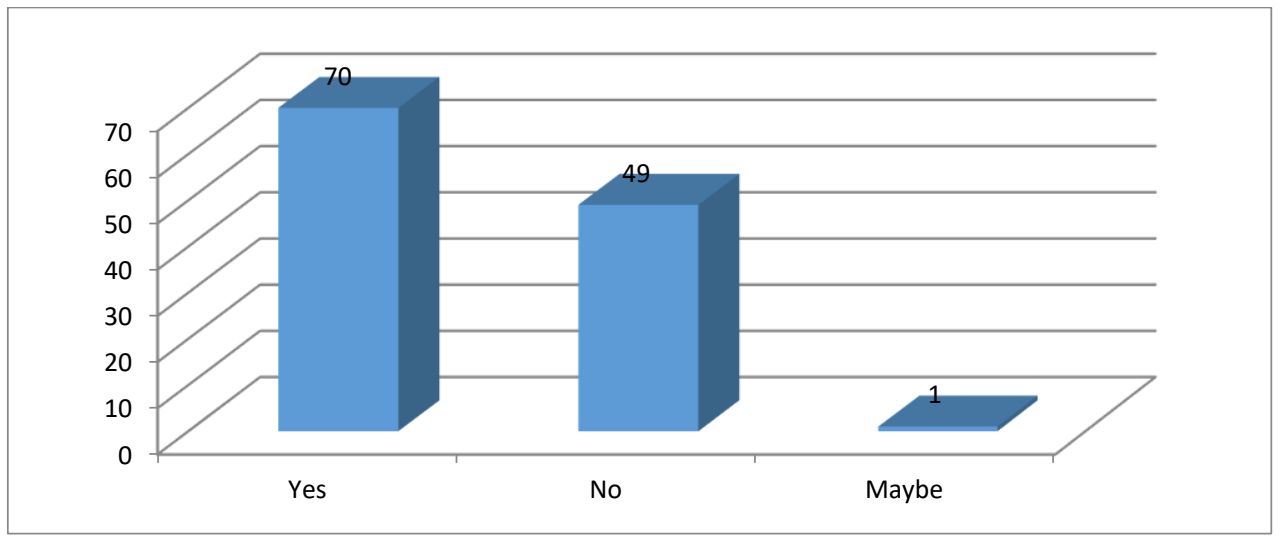

${ }^{1}$ All figures show results in numbers, not percentage. 
Figure 3. Opinion on marriage in general (Question \# 19: Everybody should get married.)

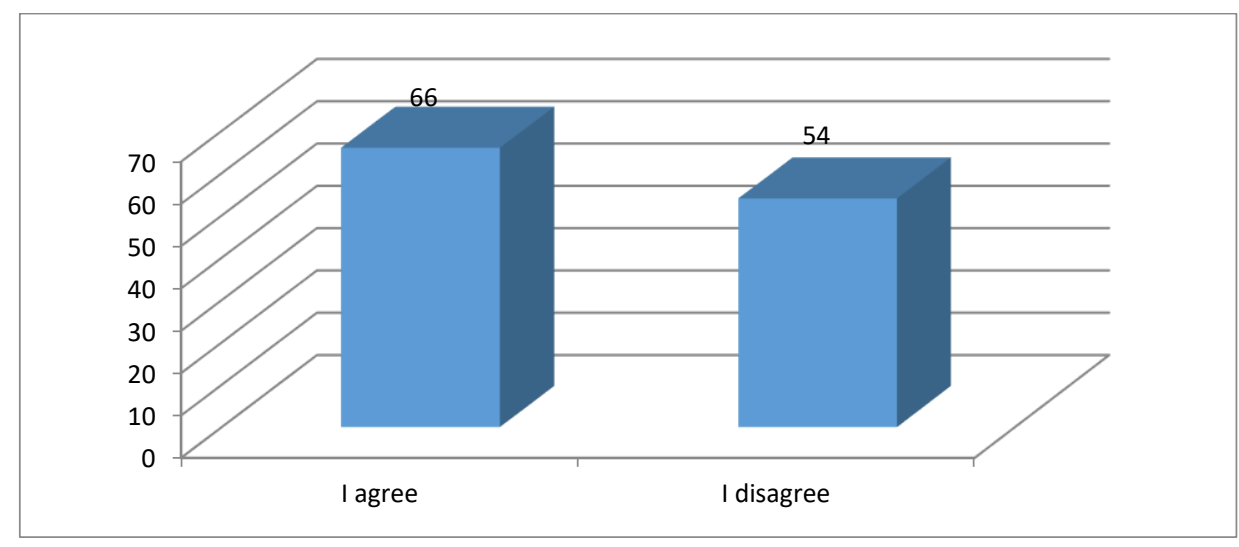

Figure 4. Opinion on marriage, divorce and reconstituted families (Question \#27: Would you be in a relationship/marriage with a partner who has children from a previous relationship/marriage?)

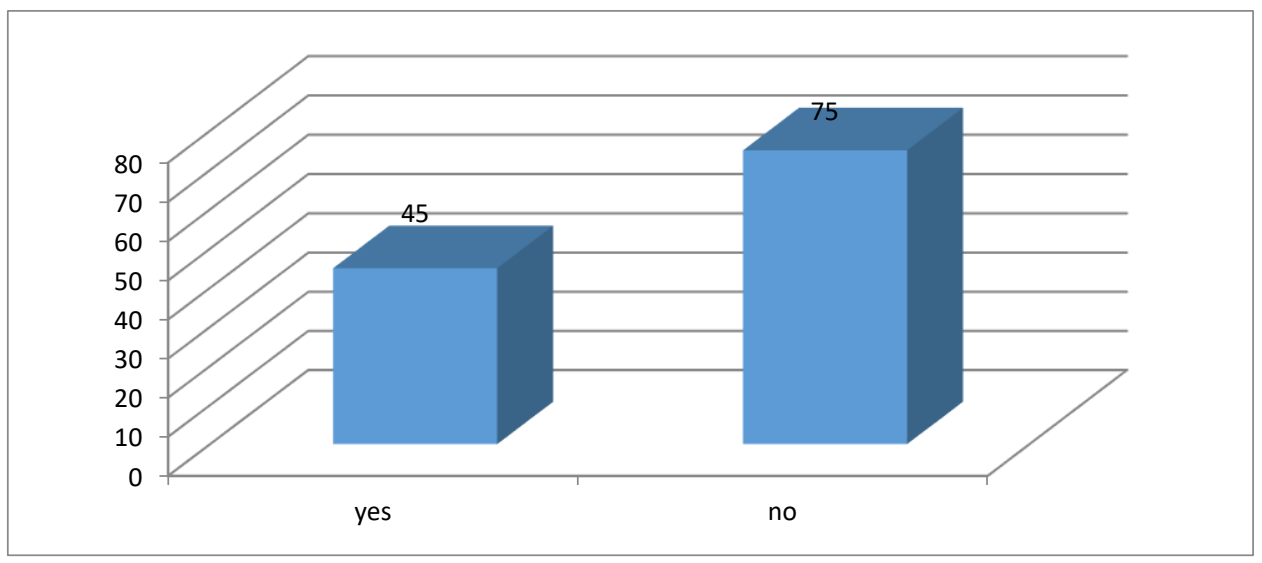

The multigenerational type of family commonly known in the region by the term "zadruga" was characteristic for the Balkans until the late $19^{\text {th }}$ and the early $20^{\text {th }}$ century. Besides having more than two generations residing in the same household, it was generally a patriarchal type of family i.e. once a woman got married she used to go to live with her husband's parents, where his unmarried sisters and married brothers lived as well. Today we consider this family structure almost extinct in the big cities, particularly in the capital Skopje, but it is still present in the rural areas, especially among Muslim population. However, we were surprised from the number of respondents living in extended families (28 out of 120), which was higher than the number of respondents living in single-parent families (17). In fact, high unemployment rate and rental prices frequently force young married couples to live with their parents. In this context, we asked our respondents whether it is acceptable for them to live with their or their partner's parents after marriage. As expected, the majority of them would prefer to live solely with their partner $(80 \%)$ and only a small group would accept to live with their parents $(8,3 \%)$ or their partner's parents $(11,6 \%)$. 
Figure 5. Question \# 7: In what type of family do you live?

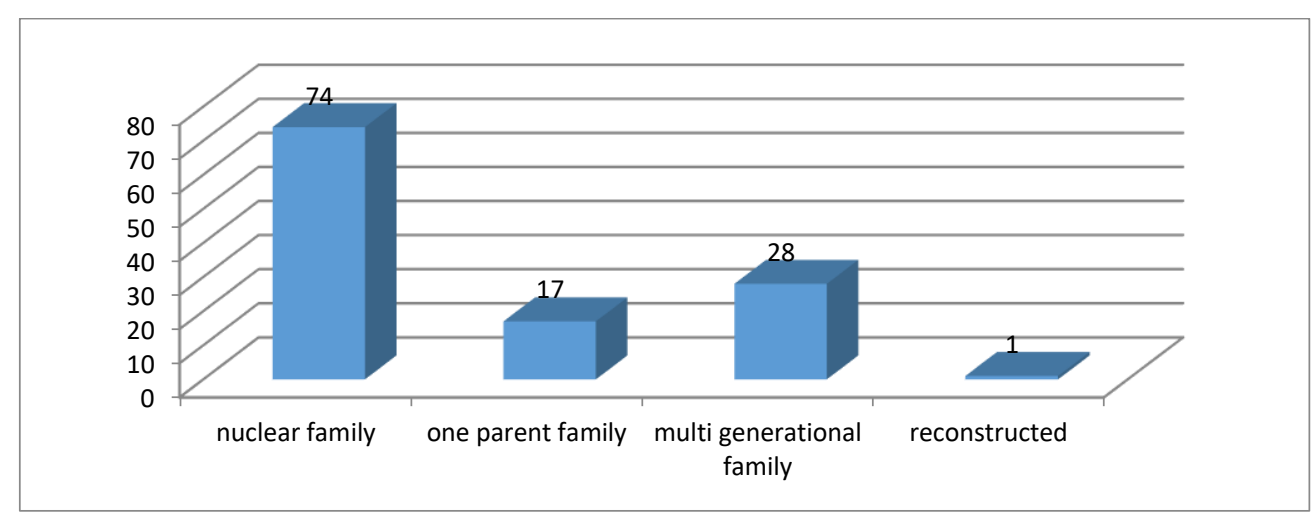

Figure 6. Opinion on multi-generation families (Question 32: "After getting married I would accept living with...")

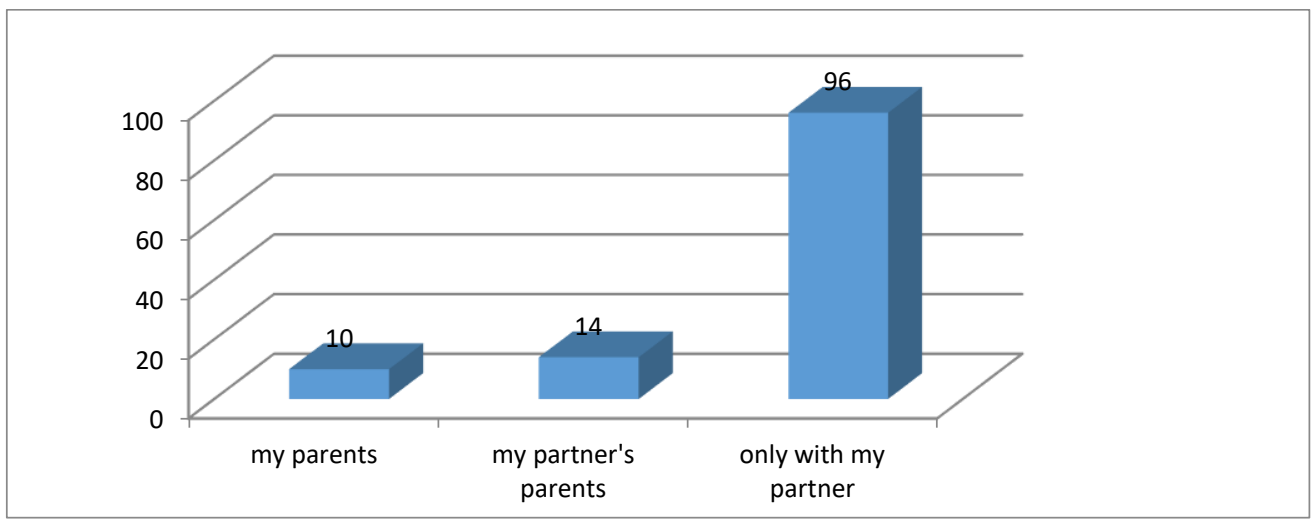

The general outcome of the questionnaire regarding the section devoted to marriage was more expected than surprising. In fact, all answers suggest a rather positive perception of marriage which might be influenced by the type of families the respondents are coming from i.e. marital communities. Even when asked whether people lose themselves in marriage, $73,3 \%$ disagree in comparison to the $26,6 \%$ who agree with the statement.

The section on divorce and children was not included in this paper due to limitation in space and coherence with the topic. Overall, young generation tend to accept divorce more than the generation of their parents and elderly, and they are more open-minded when it comes to relationships with divorced people or partners with children.

The section devoted on de facto partnership, which is also the main focus of our research, shows that cohabitation is an increasingly common idea among young people. Namely, for the majority of Macedonian youth (65\%) pre-matrimonial cohabitation with the partner leads to a successful marriage. With increased mobility from rural to urban areas and particularly towards the capital Skopje, students almost certainly already live without their parents. As a result, they have the possibility to live either with roommates or a romantic partner. In this case, cohabitation with the partner is most likely to happen, whether it leads to marriage or not. Certainly, being "anonymous" in the big city furthermore eliminates the negative perception from family and surroundings on extramarital communities. In this regard, however, our respondents consider de facto partnerships not yet widely morally accepted in the Macedonian society $(68,3 \%)$. This might be a consequence of multiple factors. Firstly, they come from an environment where marital communities are the norm (see results from question 10 above) and as studies suggest, children tend to accept their origin family structure, which will 
probably resemble their own future family as well. Secondly, given their young age (18-22), our respondents probably do not know many couples living together and have not faced the matter in real life. Thirdly, reduced youth mobility abroad ${ }^{1}$ is another factor which limits their possibility to meet and accept new types people and hence, of families. Finally, influence from older family members (as shown from the results of question \# 46, parents opinion is very important for our respondents in regard to marriage and cohabitation) and the society in general might have an impact on their opinion as well. All the above-mentioned factors might be the reason of the juxtaposition of the results from the two previous questions.

Figure 7. Opinion on pre-matrimonial cohabitation (Question \#44: Pre-matrimonial cohabitation with the partner leads to a successful marriage.)

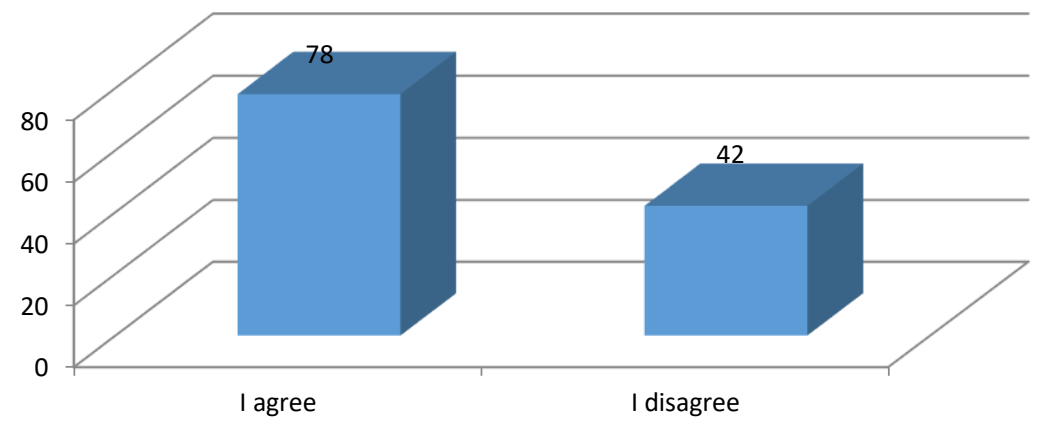

Figure 8. Opinion on cohabitation and moral standards (Question \#43: Is cohabitation morally accepted in Macedonia?)

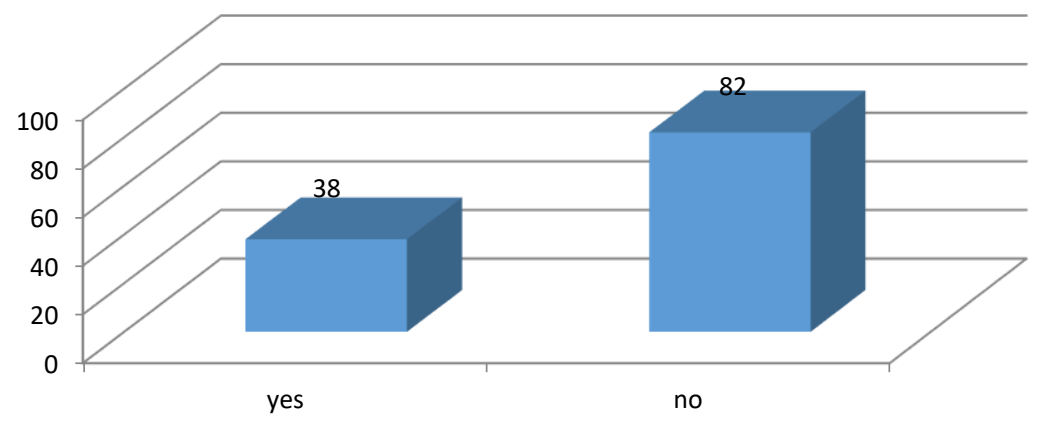

Even though many changes have occurred in the past two decades, pressure from family and society to get married at a reasonable age are still present in Macedonia. Thus, the majority of respondents $(58,3 \%)$ would not live in an extra-marital community and would prefer to get married with the partner. These results were confirmed with the answers from the following questions as well. When asked in what circumstances would they accept a de facto partnership, the majority of our respondents choose engagement $(40 \%)$ and "trial marriage" $(31,6 \%)$ as main conditions. This result suggests that cohabitation with a romantic partner is perceived predominantly as a step towards marriage but not yet as replacement for

\footnotetext{
${ }^{1}$ The Republic of Macedonia is a candidate country of the European Union since 2005 and students only enjoy limited number of exchange programs within the Union (Erasmus, Erasmus +, Erasmus Mundus etc.). Until 2010, mobility was furthermore restricted due to the EU Schengen visa regime, which some member states (for instance the United Kingdom) still require. The continuous high unemployment rate since its independence in 1991 and expensive airfare until recent years are other factors contributing to a diminished mobility of Macedonians in general.
} 
marriage and confirms general trends of cohabitation leading to marriage. Since a large part of the students still live with their parents, interestingly, $13,3 \%$ of them answered that in order to live without their parents they would accept a de facto partnership. This result is understandable, given the age of our respondents and their need for more privacy and independence. Moreover, since $23,3 \%$ (question \# 7 ) of them live in a multi-generation family, an extramarital community might be seen as a way to escape from a crowded household.

Figure 9. Opinion on extra-marital communities (Question \#42: Would you accept living in an extra-marital community with your partner?)

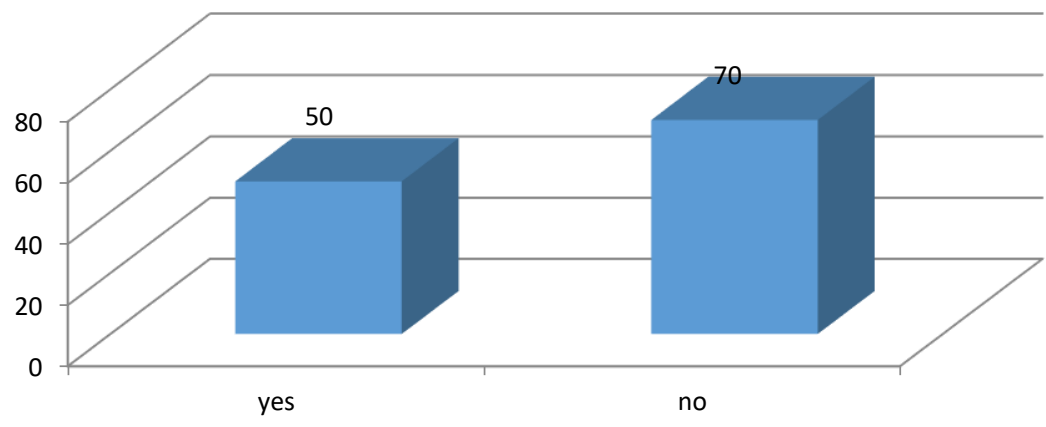

Figure 10. Question \# 45: In what circumstances would you accept living in a de facto partnership?

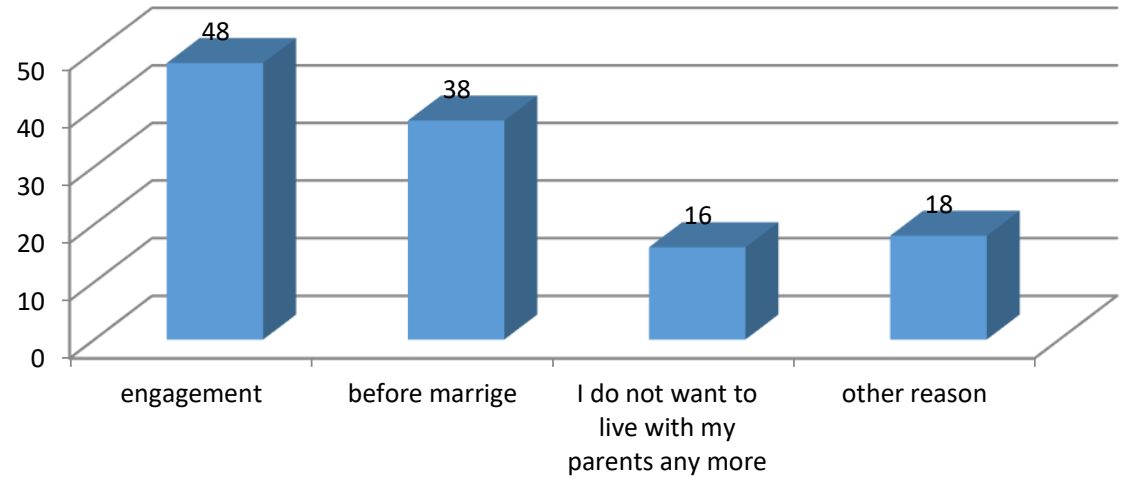

The same pattern of answers can be noted in the further results of the research. For instance, 62 respondents assume that their parents would not agree if they choose to live in a de facto partnership in comparison with 58 with the opposite estimation. This relates to the similar figures regarding their opinion on cohabitation, which means that parents' judgment on whether to get married or not are crucial for this generation. However, even when their personal opinion was questioned, marriage resulted to be very important. In fact, $73,3 \%$ of students would not live with a partner who does not want or believe in marriage. 
Figure 11. Opinion on parents' view on cohabitation (Question \# 46: Would you parents agree if you decide to live in a de facto partnership?)

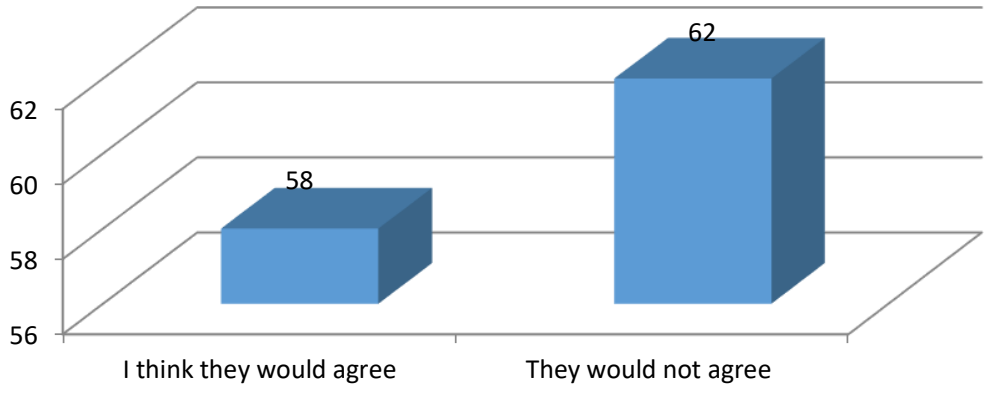

Figure 12. Opinion on cohabitation, marriage and partners (Question \# 47: Would you live with a partner who does not want or believe in marriage?)

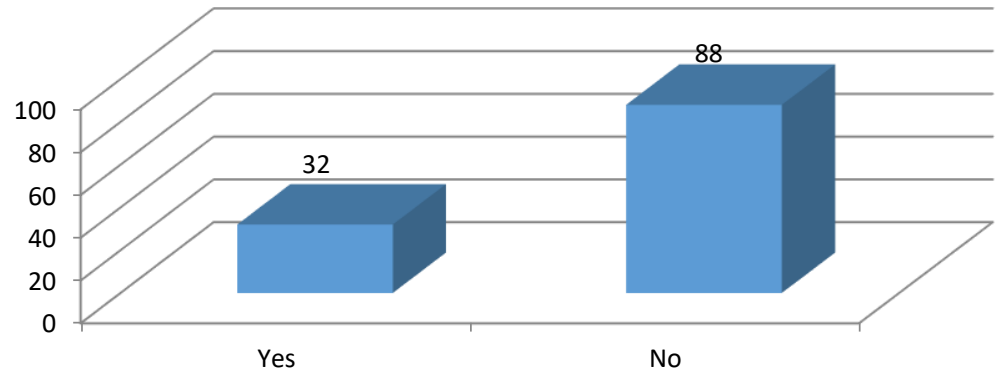

Finally, we wanted to explore the ground for possible future research and we asked our respondent to express their opinion on illegitimate children. In this regard their view was very divided, with the slight majority having a negative attitude on the matter: 55 respondents would accept the idea of women having children outside marriage in contrast to 65 who still not accept illegitimate children as common in our society.

Figure 13. Opinion on illegitimate children (Question \# 48: Women should have children outside marriage.)

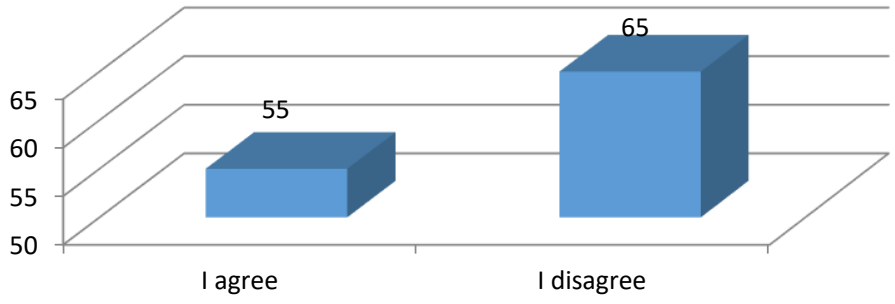




\section{Conclusion}

The final remarks of our research and the topic of cohabitation refer primarily to the changing attitude of youth towards the concepts of marriage, divorce and de facto relationship. Undoubtedly, the processes of modernization and globalization and the media had an impact and continue to influence new generations in their way of thinking and accepting new forms of families. As a consequence, if divorce and cohabitations were uncommon in traditional Macedonian society until two to three decades ago, today, they are recognized as normal and regular phenomena. However, the opinion remains divided particularly when it comes to extra-marital communities. Our respondents tend to perceive positively the concept of cohabitation, but when it comes to their personal experience, they would still prefer to get married. Marriage in Macedonian society is still considered as a more stable institution and morally embraced then de facto partnership. On the other hand, today the idea of divorce seems to be more accepted than in the past, with a slight retention when it comes to personal experience. In fact, almost half of our respondents would not gladly date a divorced person.

Even though among experts and media in Macedonia there is a general opinion that traditional forms of marriage and family style are disappearing, our research shows clear tendencies to preserve and accept marriage and marital life in general. However, if we take into account that cohabitation, relationship with divorced partners and illegitimate children were taboo topics in our country and region in general, it appears from our results that there is a progressive view on the abovementioned family models and alternative lifestyle, especially when it comes to approve the actions of others. We could assume that in the future, predominantly as a consequence of the process of globalization, the idea of cohabitation will be accepted more widely. Nevertheless, when it comes to marriage as an institutional form of coexistence, in Macedonia it will not be replaced by cohabitation in the near future.

Furthermore, our research has opened more questions which should be analyzed in depth in the future:

- Is cohabitation a stable form of family model or style?

- How much is Macedonian society ready for this alternative lifestyle?

- Will cohabitation substitute traditional marriage in Macedonia?

- Is cohabitation accepted by all ethnic groups in multicultural Macedonia? ${ }^{1}$

Finally, some findings regarding youth's opinion on same-sex couples and their right to adopt children has already caught our attention for a forthcoming project.

\section{References}

[1] Abot, E. (2014). Istorija braka. Beograd: Geopoetika izdavaštvo.

[2] Announcement on Marriages and Divorces by the State Statistical Office of the Republic of Macedonia, 11/06/2015.Retrieved from: http://www.stat.gov.mk/PrikaziSoopstenie.aspx?rbrtxt=11 (17/03/2016)

\footnotetext{
1 The Republic of Macedonia represents a multiethnic society, where Macedonians $(64,18 \%)$ and Albanians $(25,17 \%)$ constitute the major two groups of the overall population. Other minorities are as follows: Turks $(3,85 \%)$, Roma $(2,66 \%)$, Serbs $(1,78 \%)$, Bosniacs $(0,84 \%)$ and Vlachs $(0,48 \%)$. Besides different tradition and culture among each ethnic group, there is a historical difference between Christian and Muslim population in the country. Data from State Statistical Office of the Republic of Macedonia (2004). Census of Population, Households and Dwellings in the Republic of Macedonia, 2002, Final Data, Book I-Total Population according to Reasons of Presence-Absence, Age, Sex and Ethnic Affiliation, Skopje: State Statistical Office of the Republic of Macedonia, pp. 171-176.
} 
[3] Announcement on Marriages and Divorces by the State Statistical Office of the Republic of Macedonia, 08/06/2010. Retrieved from: http://www.stat.gov.mk/PrikaziSoopstenie.aspx?id=11\&rbr=95 (17/03/2016)

[4] Announcements on Birth Rates (2010-2015) by the State Statistical Office of the Republic of Macedonia. Retrieved from: http://www.stat.gov.mk/PrethodniSoopstenijaOblast.aspx?id=8\&rbrObl=2 (17/03/2016)

[5] Announcements on Population (2010-2015) by the State Statistical Office of the Republic of Macedonia. Retrieved from: http://www.stat.gov.mk/PrikaziSoopstenie. $a s p x ? i d=8 \&$ rbr=1723 $(17 / 03 / 2016)$

[6] Борнарова, С. (2012). Социјална работа во семејството, Скопје: Универзитет Св. Кирил и Методиј, Филозофрски факултет.

[7] Cheal D. (2008). Families in Today's World, A Comparative Approach. London; New York: Routledge.

[8] Coleman, J. (1984). Intimate Relationships, Marriage and Family, Indianopolis: Bobbs-Merrill Educational Publishing.

[9] Family Law, revised text, Part I, Art. 13, General Provisions. Retrieved from: http://www.mtsp.gov.mk/wbstorage/files/zakon_semejstvo_osnoven.pdf (13/11/2015)

[10] Hill, S. (2012). The evolution of families and marriages. In Contemporary Family Perspectives: Families: A social class perspective (pp.1-29). Thousend Oaks, CA: SAGE Publications, Inc.

[11] Jamieson, L. (1998). Intimacy, Personal Relationships in Modern Societies, Cambridge: Polity Press.

[12] Мицковиќ Д. (2008). Семејството во Европа XVI-XXI век, Скопје: Блесок.

[13] Murdock, G. P. (1960). Social Structure. New York: Macmillan.

[14] Радуловиќ, М. (2014). Традицијата во европските и македонските семејства. Скопје: Култура.

[15] State Statistical Office of the Republic of Macedonia (2004). Census of Population, Households and Dwellings in the Republic of Macedonia, 2002, Final Data Book XIII - Total Population according to Territorial Organization of the Republic of Macedonia. Skopje:

[16] State Statistical Office of the Republic of Macedonia.

[17] State Statistical Office of the Republic of Macedonia (2004). Census of Population, Households and Dwellings in the Republic of Macedonia, 2002, Final Data Book I - Total Population according to Reasons of PresenceAbsence, Age, Sex and Ethnic Affiliation.

[18] Skopje: State Statistical Office of the Republic of Macedonia.

[19] Share of Live Births outside Marriage according to Eurostat. Retrived from: http://ec.europa.eu/eurostat/tgm/table.do?tab=table\&init=1\&language=en\&pcode=tps00018\&plugin=1 $(16 / 03 / 2016)$

[20] Чокревски, Т. (2001). Социологија на правото. Скопје: НИП Студентски збор, Правен факултет.

[21] Џорџ, Р.П.,Елштејн, Џ.Б. (2013). значењето на бракот: Семејството, државата, пазарот и моралот. Скопје: Арс Алмина. 